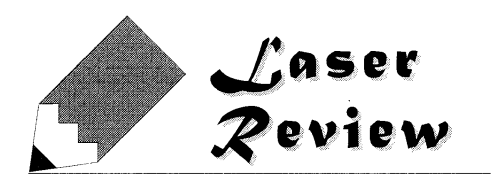

\title{
生体分子の1分子蛍光イメージング
}

\author{
船津 高志 \\ 東京大学大学院 薬学系研究科生体分析化学教室 ( ₹113-0033東京都文京区本郷7-3-1)
}

\section{Single Molecule Imaging of Biomolecules}

\author{
Takashi FUNATSU \\ Laboratory of Bio-Analytical Chemistry, Graduate School of Pharmaceutical Sciences, The University of Tokyo, \\ 7-3-1, Hongo, Bunkyo-ku, Tokyo 113-0033
}

(Received September 13, 2005)

\begin{abstract}
Recent progress of the optical microscopy, especially the nearfield microscopy, has enabled us to study functions and interactions of protein molecules at single molecular level. Single molecule imaging has become an indispensable technique to life science research. On one hand, after the determination of the whole DNA sequences of human genome, the remained issues are elucidation of the functions of genes. Single-molecule imaging technique is expected to greatly contribute to such problems. Here, I review and survey the functional analysis of biomolecules by single-molecule imaging and manipulation.
\end{abstract}

Key Words: Fluorescence, Fluorescence microscopy, Evanescent field, Single molecule imaging

1.はじめに

ゲノムの塩基配列が決められ，次の目標として残った のは，実際に発現している遺伝子は何か，その遺伝子産 物(主にタンパク質)は，何時どの細胞でどのように発現し ているのか，そして機能は何かという問題である.1分子 蛍光イメージング法は，これらの問題を解明するための 基盤技術を提供すると期待されている．既に，1分子蛍光 イメージング法を用いて，1分子の酵素反応 ${ }^{1,2)}$ ，モーター タンパク質の運動3-5)，タンパク質間相互作用6,7)がイメー ジングされている。さらに，細胞表面での受容体とリガ ンドの結合8)などが研究されている，以下では，エバネッ セント場を使った1分子イメージングの研究例を紹介す る.

\section{1分子蛍光イメージングの原理}

2.1 蛍光顕微鏡による1分子観察の歴史

タンパク質の大きさは光の波長よりもずっと小さいの で，これを検出するには特別の工夫が必要である。生体 分子に蛍光色素を結合させ，蛍光によって分子の存在が 分かるようにしたのが蛍光顕微鏡法である. 蛍光とは, 色素分子が光のエネルギーを吸収して再び光を放射する 現象であり，一般に吸収した光の波長よりも放射する蛍 光波長の方が長くなる，そのため，色素をレーザー光で 励起して, その励起光を光学フィルターで除いて蛍光の
放射光のみを検出するようにすれば，高感度な検出が可 能になる，励起光が少しでも検出器に入ってくると蛍光

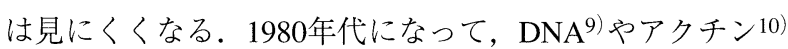
(筋タンパク質の一種)などの繊維状の巨大分子を，1分子 レベルで蛍光顕微鏡観察できるようになったが，これら の観察は, 生体分子に数百個の蛍光色素を結合させて, ようやく見えるものだった。1分子の蛍光色素は超高感度 カメラならば検出可能な数の光を放出しているが，強い 励起光をあてると様々な光学部品より蛍光が発生し背景 光となるため, この背景光をいかにして少なくするかが1 分子観測の最大の問題点であった．1990年代になって， 顕微鏡部品の改良などによって, 背景光の問題を解決す ることにより，1分子の蛍光観察が可能になった1,11).さ らに，「エバネッセント場」を利用した局所励起を行うこと により，1分子の生体分子が酵素反応している様子1)や運 動している様子3) をイメージングすることが可能となっ た.

\section{2 エバネッセント場による局所励起}

伝播光を使って蛍光色素を局所励起するために，レー ザー光を回折限界まで集光させる方法がとられる。しか し, この方法では励起する領域は波長の半分程度の広が りをもってしまう。さらに照射領域を小さくする方法と して，エバネッセント場(消滅場)を利用する方法がある. エバネッセント場が発生する代表的な例として，金属 コートした光ファイバの先端に入射光の波長よりも小さ 
い微小開口を設ける方式がある(Fig. 1 (a)). 開口径50 $200 \mathrm{~nm}$ のものがプローブとして使われ，これを走査して 画像を得る顕微鏡はNSOM (Near Field Scanning Optical Microscopy)とよばれる12).これは, 光の回折限界を越え た分解能で観察が可能であること, 走査型トンネル顕微 鏡や原子間力顕微鏡などの他の走査型顕微鏡と組み合わ ることが可能であるという長所を持つ. しかし，プロー ブの制御が難しく，時間分解能が悪いという欠点がある ため，生物学へ応用することは難しかった。

エバネッセント場を発生させる最も簡単な方法は, 全 反射を利用する方法である (Fig. 1 (b)). 高屈折率の媒質 (ガラス) から低屈折率の媒質 (水溶液)に臨界角以上で光を 入射すると全反射が起こり, 低屈折率の媒質の界面近傍 にエバネッセント場が生成される。エバネッセント場 は, 界面から深さ方向に指数関数的に減衰する局所場で ある。このため, 波長よりも短い領域を照明することが できる。エバネッセント場も伝播光と同様に, 物体によ る散乱を受けたり蛍光色素を励起することが可能であ る. 散乱光や蛍光のみを伝播光として検出できるので, 背景光が極めて小さく, 1分子の蛍光色素の観察に適して いる。エバネッセント場は界面のごく近傍しか照明しな いので, 背景光を抑えられるだけでなく, 蛍光標識した 生体分子を局所励起できるという利点がある.

このように，全反射によるエバネッセント照明は，ガ ラス近傍のみを照明するのに有効であるが，2次元的には 局所励起を実現できていない。このため, ブラウン運動 する蛍光分子が背景光になり，1分子の蛍光分子を見るた めには，溶液中の分子の濃度を50 nM以下に抑える必要が あった。また，生体分子がガラスに吸着されにくい性質 であることが必要条件であった。このように厳しい制約 があるので, 多分子系の実験を, 全て一分子系の実験に 移行できるわけではなかった。しかし，ガラス基板上に 金属薄膜を蒸着し直径数十ナノメートルの微小開口を配 列させた構造が考案され, エバネッセント場が縦, 横, 奥行き方向に3次元的に制御できるようになった (Fig. 1 (c)).これを用いると, 全反射型エバネッセント照明の場 合よりも照射領域を千分の一にすることができる。この ため従来の濃度の限界より千倍も高い濃度 (数十 $\mu \mathrm{M}$ ) の生 体分子を溶液中に漂わせながら, 蛍光相関分光法や1分子 蛍光イメージング技術を用いて生体分子間相互作用をイ メージングすることができるようになった。この技術 と, DNA合成酵素が $\gamma$ リン酸を蛍光標識したヌクレオチド を取り达みながらRNAを合成するのを利用して，1分子の DNAの塩基配列を解読することが試みられている13).

\section{3. エバネッセント場蛍光顕微鏡を用いた 1分子イメージング研究}

\subsection{1分子計測の意義}

まず，1分子計測することの意義を考察する．従来の生 物科学研究では, 生体分子の性質を, 試験管内の多数分 子の平均值として表してきた。例えば，濃度 $1 \mu \mathrm{M}$, 体積 $1 \mathrm{~mL}$ 溶液中には, 約 $10^{15}$ 個の分子が含まれている。この
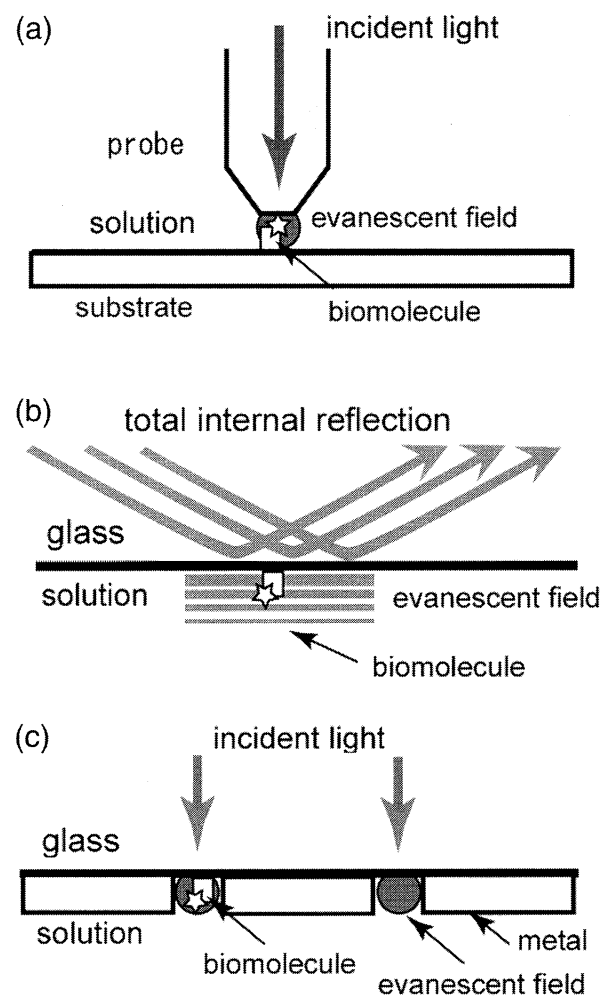

Fig. 1 The methods to generate evanescent field to excite the fluorescent molecule attached to a biomolecule. (a) Evanescent field is generated at the tip of fine needle of which aperture is smaller than the wave length of light. (b) Evanescent field is generated at the interface of glass and solution by total internal reflection. (c) Evanescent field is generated by microarrays of zero-mode wave guides.

場合, 個々の分子の平均值からのずれを表す標準偏差と 平均值との比は $10^{-7}$ 以下になり, 測定装置に由来する誤差 に比べて無視できるほど小さい。 このように, 多分子計 測では平均值を非常に正確に求めることができるが，分 子のダイナミクスを研究することは困難である. 生物分 子モーターの化学. 力学エネルギー変換のように, 1分子 が担っている2種類の反応のタイミングを明らかにするに は，1分子ごとに計測しない限り不可能である14). 多分子 計測のもう一つの欠点は, 平均值から1分子の機能を推論 するためには，「全ての分子は同様に振る舞う」という仮定 を必要とする。しかし, 1分子計測によって, 生物分子 モーターの力発生や，コレステロール酸化酵素などの酵 素作用に履歴作用があることが分かり，この仮定が必ず しも成立しないことが明らかになっている14,2). 1分子計 測は技術的に難しいが, 仮定のない明快な結論を導き出 すことができるという長所がある。ただ，1分子計測を 1回行うだけでは不十分で, 複数回の測定を行い統計的な 解析を必要とする場合が多い. 生体分子の多くはATPの加 水分解のエネルギーを利用して様々な仕事をしている が, ATPの加水分解によって利用できる自由エネルギーは わずか $10^{-19} \mathrm{~J}$ (1自由度あたりの熱エネルギーの40倍)しか ない.このため, 生体分子は, 絶えず熱摇らぎの影響を 受けており，確率論的に作用するという性質を持ってい る。したがって，1回測定しただけでは1分子の特性を十 
分に決定したことにならず，繰り返し測定して統計処理 をすることにより，はじめて生体分子の機能が明らかに なる。

\section{2 生体分子の運動を見る}

次に，生物分子モーターであるキネシンを蛍光標識 し，1分子のキネシンが微小管上を滑り運動する様子を観 察した例を紹介する (Fig. 2).タンパク質を蛍光色素で標 識する場合，タンパク質の活性を保ったまま，いかにし て特定部位に蛍光色素を結合させるかが問題となる。こ こでは，蛍光色素Cy5を結合したピューロマイシン (Cy5puro）を用いてタンパク質のC末端を蛍光標識する方法を 紹介する4)。このためには，終止コドンを欠いたキネシン DNAを用意し, Cy5-puro存在下で無細胞転写, 翻訳系を 用いてキネシンを合成する。終止コドンがないため翻訳 終了後，終結因子がリボソームに入らず，翻訳されたぺ プチド鎖がリボソームから解離できなくなる。しかし， ピューロマイシンのアミノ基がペプチジル-tRNAのペプチ ド鎖とtRNAとを結合しているエステル結合を攻撃し，よ り安定なアミド結合を形成してペプチド鎖をリボソーム から解離する。このため，C末端にCy5-puroを共有結合し たキネシンを得ることができる(Fig. 2 (a))。この方法を 用いると，キネシンのDNAを加えてから2時間以内にCy5puroキネシンを合成し，1分子機能アッセイすることが可 能である. Fig. 2 (b) は，微小管をガラスに固定し，蛍光 標識したキネシンをATPとともに加え，TIRFMで観察し た結果である。1分子のキネシンが $500 \mathrm{~nm} / \mathrm{s} の$ 速さで微小 管上を滑り運動している様子が観察された。滑り運動距 離の度数分布は，平均 $1,000 \mathrm{~nm}$ の指数分布となった。キネ シンは8 nmのステップで微小管上を移動するので，平均 120ステップで微小管から外れることになる。キネシンが (a)

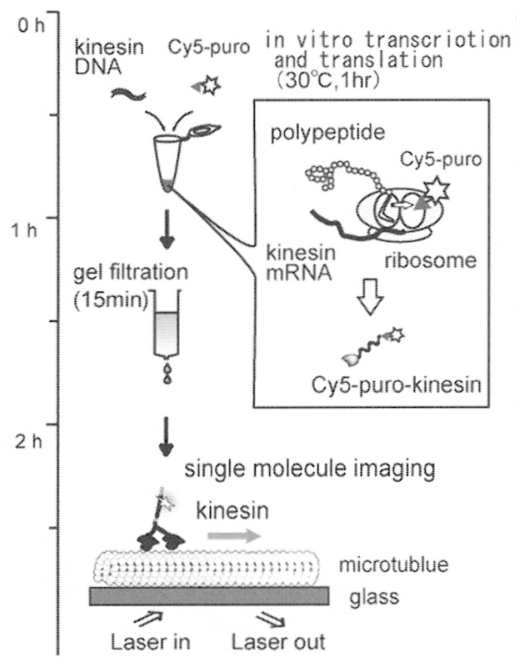

(b)

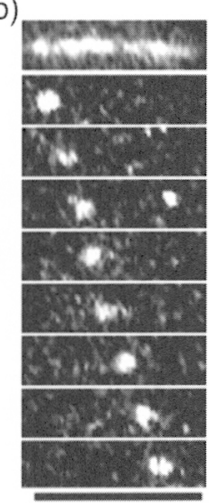

Fig. 2 Single molecule imaging of kinesin moving along a microtubule. (a) A schematic drawing of the procedure for synthesizing and analyzing function of Cy5puro-kinesin. (b) Movement of single Cy5-purokinesin molecules along a microtubule. Fluorescence micrographs of a microtubule (top panel) and serial micrographs of Cy5-puro-kinesin molecules (time in seconds). Scale bar, $5 \mu \mathrm{m}$.
微小管から一度でも離れるとブラウン運動で拡散してし まうため，外れるまでの平均ステップ数からキネシンが 結合・解離の運動サイクルのうち $99 \%$ 以上, 微小管に結 合したままでいることを直接示せたことになる。

蛍光色素が放出した光子をカメラなどで検出する場 合，光の回折により波長の1/2程度に広がってしまう。し かし，単一蛍光分子小らの蛍光 $(10, \Theta 00$ 光子)の輝度分布を 冷却CCDカメラで撮影して解析すれば，中心位置を0.5秒 の時間分解能， $1.5 \mathrm{~nm}$ の精度で検出できる5)。また，マイ クロメートルのサイズのビーズを用いて強力な直接光や 散乱光で検出した場合，サブミリ秒の時間分解能， $1 \mathrm{~nm}$ の精度で解析が可能である15).

\section{3 タンパク質分子間相互作用を見る}

1分子イメージングによるタンパク質相互作用の研究例 をシャペロニンによるタンパク質折りたたみ機構を例 として解説する。タンパク質が機能を発揮するために は，ポリペプチドが正しく折れたたまれ，ある立体構造 を形成する必要がある。この折りたたみを助けているの が分子シャペロンである。様々な分子シャペロンの中 で，最も研究が進んでいるのが大腸菌のGroELである. GroELは7つのサブユニット (分子量 $57 \mathrm{k}$ ) からなる「かご」状 のリングが2層に重なった構造をしている. GroELにATP が結合すると補助因子である「ふた」状のGroESと結合して 巨大な空洞をもった複合体を形成する。この空洞の中で シャペロニンの基質となるタンパク質の折りたたみが起 こる。蛍光色素IC5で標識したGroELをガラスに固定し， 変性タンパク質とATP存在下で蛍光標識したGroESが GroELに結合・解離するダイナミクス在観察した。 GroEL をガラス基板の固定し，別の蛍光色素Cy 3 で標識した GroES 溶液中に加えGroELと結合・解離する様子を観察 した(Fig. 3 (a))。GroESのブラウン運動は非常に早いの で，ビデオでは蛍光の輝点として観察されず背景光とな るだけである。従って，ブラウン運動する分子は見え ず，結合して止まった分子だけを観察できるのである。 このように，分子のブラウン運動と全反射による局所励 起を巧みに組み合わせることにより，GroELとGroESの1 分子間相互作用をイメージングすることが可能になった (Fig. $3($ b)). GroESの結合時間を解析した結果，GroES は，ある中間体を経てから解離する二段階反応であり， それぞれの反応の時定数は3秒と5秒と見積もられた(Fig. 3 (c)). 次に，この中間体がどのような役割を果たしている のかを明らかにするため, シャペロニン分子内で起こる 恋性タンパク質の折れたたみを1分子イメージングした。 このために，変性したGFPは蛍光を発しないが折りたたむ と再び蛍光を発する性質を利用した。まず，酸変性させ たGFPをGroELの入った溶液に希釈し，変性GFP-GroEL複 合体を作製し，スライドガラス上に固定した。その後 GroES とCaged ATP (ATPに保護基を結合させて不活化した 化合物。紫外光照射により保護基が分解しミリ秒でATPが 生成される)を加え，顕微鏡下で紫外線を照射してATPを 生成し，シャペロニンの反応を開始させた。その結果， 紫外線照射後，3秒たってからGFPの蛍光が現れた。この 
(a)

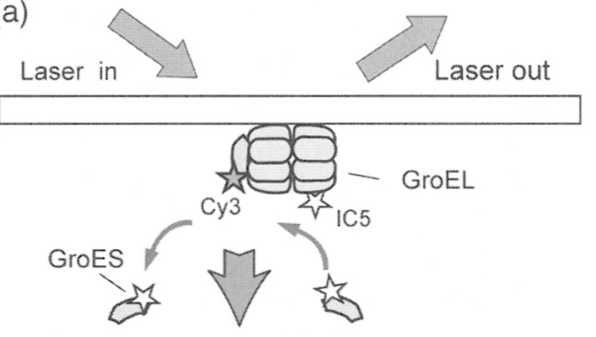

(b)

Fluorescence
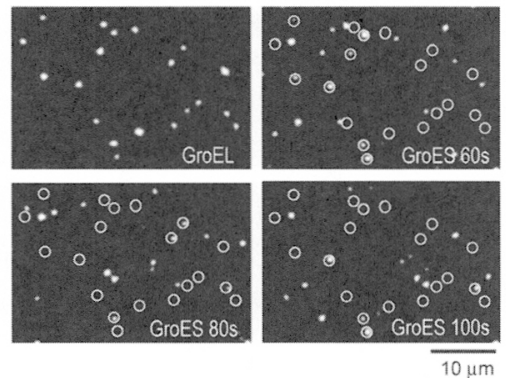

(c)

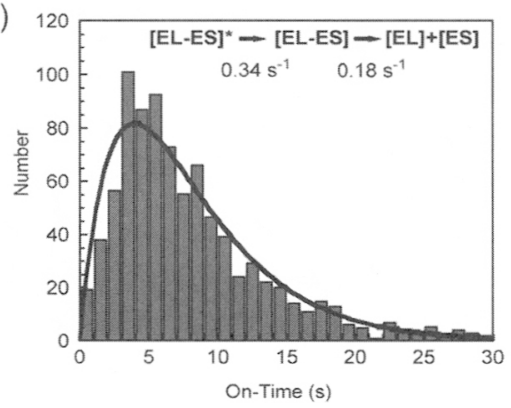

Fig. 3 Single-molecule imaging of chaperonin GroELGroES dynamics. (a) Schematic drawing of the experiment. (b) Fluorescence images of single GroEL and GroES molecules. (c) Histogram of the duration of 'on-time'. The solid line was fit to the data by least squares fitting.

ようにして，1分子のタンパク質がフォールディングする ところを初めてイメージングすることに成功し，シャぺ ロニンによるタンパク質折りたたみに特徵的な3秒のタイ ムラグが明らかになった。新たに見つかったGroEL中間体 は, GroESと変性タンパク質を両方結合していることを示 している. GroELは, 変性タンパク質, GroESと順を追っ て解離することで確実に基質タンパク質を自らの空洞に 閉じ込めていることが，1分子蛍光イメージング法によっ て明らかになった7)。

\section{4 酵素反応を見る}

1分子の蛍光分子が見えるので，蛍光色素で標識した任 意の生体分子をイメージングできる。ATPなどの基質に蛍 光性物質を結合させる技術が平塚らによって考案され， TNP-ATP ${ }^{16)}$, MANT-ATP ${ }^{17)}$ が合成され, その有効性が示 されている。私たちは，ATPに蛍光色素Cy3を結合させた Cy3-ATP (Fig. 4 (a))を用いて，筋肉の生物分子モーターで あるミオシン1分子が1分子のATPを加水分解している様子. を直接イメージングした1）。ここで，1分子のATPase反応 のイメージング法の原理について解説する (Fig. 4 (b)). まず，ガラス表面上にCy5で蛍光標識したミオシン分子を
固定し, ミオシン分子の位置を確認する。次に, Cy3-ATP を加える。エバネッセント照明では，ガラス基板から約 $150 \mathrm{~nm}$ の距離にいる蛍光色素しか励起されない. ミオシ ンに結合していないCy3-ATPはブラウン運動をしているた め，たとえ照射領域に入ったとしても蛍光スポットとし て観察されず背景光となるだけである。Cy3-ATPがミオシ ンに結合するとブラウン運動が制限され, 初めて輝点と して観察できるようになる.Cy3-ATPがミオシン分子上で 加水分解され, Cy3-ADPが解離すると再び暗くなる。こ の光の点滅によってATPのターンオーバーをイメージング する.

1分子イメージングと光ピンセットによるナノ分子操作 を組み合わせることにより, 生物分子モーターの化学反 応と力学反応を1分子レベルで同時計測した ${ }^{14)}$ 。このため に，まずアクチンフィラメントの両端を直径 $1 \mu \mathrm{m}$ のマ クロビーズに結合させ，光ピンセットで捕捉した．続い てアクチンフィラメントとミオシンを相互作用させ， ミ オシンが発生する数 $\mathrm{pN}$ 張力をビーズの数nmの変位から 検出した。一方，ミオシンのATPaseはCy3-ATPの蛍光強 度変化から求めた。 その結果, ヌクレオチドの放出から 数十から数百ミリ秒遅れて力を発生する事例が確認され た。この現象は, 生物分子モーターの力発生がATPの加水 分解あるいは，無機リン酸やADPの解離と共役している とする今までの説では説明できない。この結果は, 蛋白 質がATPの加水分解で受け取った自由エネルギーを内部に 貯めておき, 必要なタイミングを計って仕事をするとい う高度な機能を持っていることを示している。

以上の研究は, 基質に蛍光色素を結合させて酵素反応 をイメージングしたが，酵素が蛍光を有する場合は，こ の蛍光を利用して1分子イメージングすることが可能であ る、コレステロール酸化酵素は補酵素としてFAD (flavin adenine dinucleotide) を結合している.コレステロールの酸 化に伴ってFADが還元されてFADH 2 となり，自然酸化に

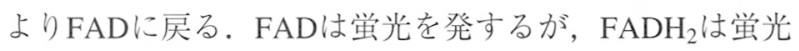

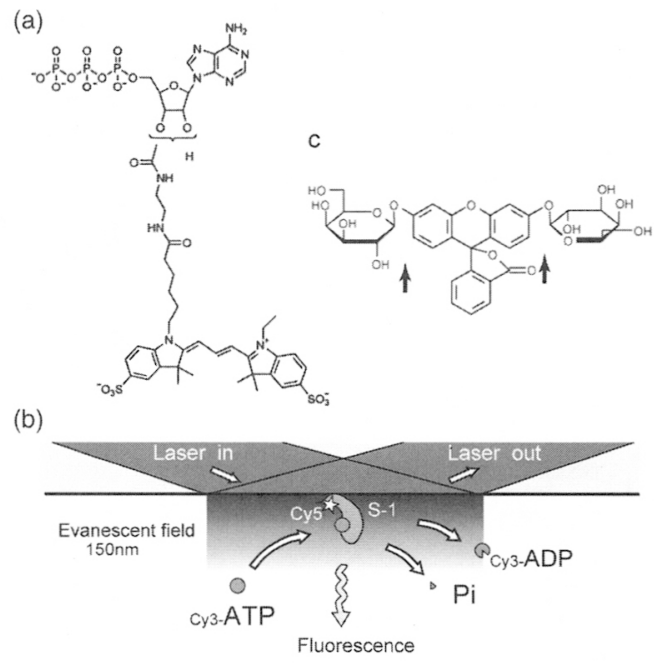

Fig. 4 Imaging of enzymatic reactions. (a) Structure of Cy3ATP. (b) Schematic drawing of the experiment. (c) Structure of fluorescein di- $\beta$-D-galactopyranoside. It emits fluorescence on cleavage of sugars indicated by arrows by $\beta$-galactosidase. 
を出さないので，この性質を利用して酵素反応が1分子イ メージングされている2). 解析の結果, 酵素反応が終了し た直後の1秒くらいの間は，次の反応が速やかに進行する ことが示された。ミオシンやコレステロール酸化酵素に 見られる履歴効果は，1分子計測によって初めて明らかに された現象である。

酵素と蛍光性基質を直接1分子イメージングする他に， 両者を微小空間に閉じ込めて酵素反応を検出する方法も 開発されている。この方法では，光透過性が高く生体試 料と相性の良いPDMSとよばれるシリコーンゴムのチャン バーが用いられる。ママイクロ加工技術を利用して， $\mathrm{fL}=$ $\mu \mathrm{m}^{3}$ の微小溶液チャンバーアレイを作製し，この中に必要 な溶液を閉じ达めて，高感度に酵素反応を検出する。実 際に， $\beta$-ガラクトシダーゼをモデル酵素, fluorescein di$\beta$-D-galactopyranoside(FDG) を基質としてこの方法の有効 性が示されている18).FDGはフルオレセインの両端に糖 を結合させて無蛍光にした分子である (Fig. 4 (c))． $\beta$-ガ ラクトシダーゼが糖を切断すると，フルオレセインが蛍 光を発するようになり，微小溶液チャンバー内で酵素反 応が高感度に検出された。1分子イメージングよりも単純 で計測が容易なため，酵素反応だけでなく，1細胞解析や 1分子DNA解析など，広範囲の応用が期待されている.

\section{4. 新しい蛍光標識材料}

\section{1 蛍光タンパク質}

計測技術が急速な進歩を遂げる一方で，有用な蛍光物 質が次々に開発されている。従来は，有機蛍光色素分子 を用いてタンパク質を標識していたが，GFPを用いてタン パク質を光らせるという画期的な技術が開発された。GFP は1960年代にオワンクラゲ(Aequorea)より単離されたタン パク質である. GFPは蛍光を発するための特殊な発光素や 補因子を必要とせず，GFPのペプチド自身の構造変化に よって発色団を形成する。すなわち，GFPが生物の体内で 作られると自然に蛍光を出すようになる。1990年代にGFP の遺伝子配列が明らかになると，すごい勢いで細胞生物 学の分野で利用されるようになった ${ }^{19)}$. GFPと様々なタン パク質との融合タンパク質が作られ，ついに，緑色に光 る大腸菌，線虫，マウスなどの生物が登場した。これに より，遺伝子の発現を生きたままGFPの蛍光によって容易 に捉えることができるようになった．現在では，GFPのア ミノ酸配列を改変したり，イソギンチャクなど，クラゲ 以外の生物の蛍光タンパク質が検索され，より明るく， 様々な波長の蛍光を発する蛍光タンパク質を得る試みが 続けられている，もちろん，1分子のGFPを観察すること も可能である。

\section{2 量子ドット}

有機蛍光色素に代わるものとして，量子ドットが注目 を集めている。量子ドットは原子が数十から数千個集 まった直径数ナノメートルの塊であり，ある波長の光を 照射すると別の波長の蛍光を放出する，量子ドットに閉 じ込められた電子のエネルギー順位は量子ドットのサイ
ズに応じて変化するので，サイズを変えることにより蛍 光波長を選択できる。材質がCdSeならば青から赤, InPや InASならば近赤外から赤外の蛍光を利用できる. CdSeを

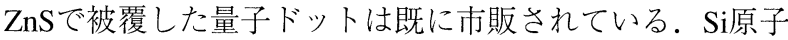
数十個からなる量子ドットも開発されている。これを用 いれば，GFPよりも小さな 1 ～ $3 \mathrm{~nm}$ の直径で青から赤まで の蛍光波長を選択できる。量子ドットは広い吸収スペク トルをもち，一方，蛍光のスペクトル幅は狭い。このた め，1色の励起光で多色の量子ドットを同時に励起するこ とが可能である．蛍光の異なる量子ドットの比率を変え てマイクロビーズに埋め込むことにより数万種類のID化 が可能である20)。量子ドットは量子效率が30～ $50 \%$ と高 く，モル吸光係数も $1 \times 10^{6} \mathrm{M}^{-1} \mathrm{~cm}^{-1}$ と大きく，非常に明 るい，また，有機色素よりも約100倍光に対して安定であ る(すなわち退色しにくい)。このため, 細胞内で単一の量 子ドットを長時間にわたって観察することも可能である.

\section{5. おわりに}

量子ドットや微小開口列を用いた1分子蛍光イメージン グ技術が象徴するように，ナノテクノロジーによる蛍光 材料や反応基板の製作が単一分子計測に必要不可欠にな りつつある.バイオテクノロジーとナノテクノロジーが 融合することにより，より大きな発展が期待される。

\section{参考文献}

1) T. Funatsu, Y. Harada, M. Tokunaga, K. Saito, and T. Yanagida: Nature 374 (1995) 555.

2) H. P. Lu, L. Xun, and X. S. Xie: Science 282 (1998) 1877.

3) R. D. Vale, T. Funatsu, D. W. Pierce, L. Romberg, Y. Harada, and T. Yanagida: Nature 380 (1996) 451.

4) J. Yamaguchi, N. Nemoto, T. Sasaki, A. Tokumasu, Y. MimoriKiyosue, T. Yagi, and T. Funatsu: FEBS. Lett. 502 (2001) 79.

5) A. Yildiz, J. N. Forkey, S. A. McKinney, T. Ha, Y. E. Goldman, and P. R. Selvin: Science 300 (2003) 2061.

6) H. Taguchi, T. Ueno, H. Tadakuma, M. Yoshida, and T. Funatsu: Nat. Biotechnol. 19 (2001) 861.

7) T. Ueno, H. Taguchi, H. Tadakuma, M. Yoshida, and T. Funatsu: Mol. Cell. 14 (2004) 423.

8) Y. Sako, S. Minoghchi, and T. Yanagida: Nat. Cell. Biol. 2 (2000) 168.

9) K. Morikawa and M. Yanagida: J. Biochem. (Tokyo) 89 (1981) 693.

10) T. Yanagida, M. Nakase, K. Nishiyama, and F. Oosawa: Nature 307 (1984) 58

11) I. Sase, H. Miyata, J. E. Corrie, J. S. Craik, and K. Kinosita, Jr.: Biophys. J. 69 (1995) 323.

12) E. Betzig and R. J. Chichester: Science 262 (1993) 1422.

13) M. J. Levene, J. Korlach, S. W. Turner, M. Foquet, H. G. Craighead, and W. W. Webb: Science 299 (2003) 682.

14) A. Ishijima, H. Kojima, T. Funatsu, M. Tokunaga, H. Higuchi, H. Tanaka, and T. Yanagida: Cell. 92 (1998) 161.

15) R. Yasuda, H. Noji, M. Yoshida, K. Kinosita, Jr., and H. Itoh: Nature $\mathbf{4 1 0}$ (2001) 898

16) T. Hiratsuka: Biochim. Biophys. Acta. 453 (1976) 293.

17) T. Hiratsuka: Biochim. Biophys. Acta. 742 (1983) 496.

18) Y. Rondelez, G. Tresset, K. V. Tabata, H. Arata, H. Fujita, S. Takeuchi, and H. Noji: Nat. Biotechnol. 23 (2005) 361.

19) M. Chalfie, Y. Tu, G. Euskirchen, W. W. Ward, and D. C. Prasher: Science 263 (1994) 802

20) M. Han, X. Gao, J. Z. Su, and S. Nie: Nat. Biotechnol. 19 (2001) 631. 